\title{
ОРГАНІЗАЦІЯ РАННЬОЇ ДІАГНОСТИКИ РАКУ ШЛУНКА ВІДПОВІДНО ДО АКТУАЛЬНОГО ПОТЕНЦІАЛУ СИСТЕМИ ОХОРОНИ ЗДОРОВ'Я
}

\author{
Вінницький національний медичний університет ім. М. І. Пирогова, \\ м. Вінниця, Україна
}

\begin{abstract}
Мета: проаналізувати показники захворюваності, смертності від раку шлунка та ефективність організації онкологічної допомоги даній категорії хворих у Вінницькій області та Україні.

Матеріали і методи. Проведено епідеміологічне одномоментне ретроспективне дослідження підсумково-звітної статистичної документації Національного канцер-реєстру (www.ncru.inf.ua) з використанням методу викопіювання даних. Для оцінки організації онкологічної допомоги хворим на рак шлунка у Вінницькій області та Україні обрано такі тренди: поширеність, захворюваність, не прожили одного року з числа вперше захворілих, занедбаність, морфологічна верифрікація, охоплення спеціальним лікуванням первинних хворих, середня частота госпіталізації хворого за рік, середній ліжко-день на одного хворого і однієї госпіталізації, загальна летальність. Методи дослідження - бібліосемантичний, епідеміологічний, медико-статистичний.

Результати. Станом на 01.01.2020 р. кількість хворих на рак шлунка в Україні становила 27407 осіб (76,8 на 100 тис. населення), серед них 15146 (91,3 на 100 тис. населення) чоловіків, які в 1,5 раза переважали кількість жінок - 12201 (64,2 на 100 тис. населення). У структурі захворюваності й смертності останній посідав у чоловіків четверте $(6,9 \%)$ й друге $(9,5 \%)$, у жінок - восьме $(4,1 \%)$ й третє $(7,5 \%)$ місця відповідно протягом усього періоду спостереження. 3'ясовано, що вагомими недоліками в організації лікувально-діагностичного процесу цій категорії пацієнтів є результативні індикатори дорічної летальності та занедбаності хвороби, останній у 2019 р. склав 38,2 \% по Україні і 43,4 \% у Вінницькій області, тобто кожен третій випадок. Більшість $(55,5$ \%) 3 числа вперше виявлених не прожили одного року з моменту встановлення діагнозу, при цьому регіональні показники вищі протягом усього періоду дослідження (61,1-62,6 \%).

Висновки. Доведено, що злоякісні новоутворення шлунка в Україні характеризувались високими показниками занедбаності (38,2 \%), дорічної летальності (55,5\%), смертності у співвідношенні до показника захворюваності (73,2 \%) та збільшенням середньої частоти госпіталізації хворого за рік (2,2 раза; Пн (+) 15,8 \%).
\end{abstract}

КЛЮЧОВІ СЛОВА: рак шлунка; захворюваність; смертність; рання діагностика.

За даними International Agency for Research on Cancer, рак шлунка (РШ) серед усіх злоякісних новоутворень $(3 \mathrm{H})$ у людини є четвертою найрозповсюдженішою фрормою 3Н і другою причиною смерті від раку в світі [1]. Щорічно реєструють майже один мільйон нових випадків і 700 тис. смертей від цього захворювання у світі $[1,3,4]$, серед них 2/3 хворих на РШ виявляють у занедбаному стані, а 60 \% пацієнтів, на момент встановлення діагнозу, мали уже III або IV стадію хвороби [4]. У структурі захворюваності серед органів травлення РШ посідає друге, а в структурі смертності - перше місця $[1,3]$.

Рак шлунка в Україні, серед усіх злоякісних новоутворень людини, посідає третє місце і залишається надзвичайно гострою проблемою, однією з причин якої $є$ низький рівень виявлення ранніх його фоом, тоді як відомо, що при видаленні пухлини шлунка на ранній стадії, показник 5-річного виживання може бути 100 \% [4].

Отже, на сьогодні актуальною залишається проблема ранньої діагностики даного захворювання, яка поліпшує 5-річну виживаність хворих

(c) О. М. Комар, Н. М. Кізлова, 2020 на рак шлунка, зменшує витрати на протипухлинне лікування в спеціалізованих високотехнологічних стаціонарах, а також знижує показники смертності, що має соціально-економічне значення для здоров'я населення України та його трудового ресурсу.

Мета роботи: проаналізувати показники захворюваності, смертності від раку шлунка та есрективність організації онкологічної допомоги даній категорії хворих у Вінницькій області та Україні.

Матеріали і методи. Проведено епідеміологічне одномоментне ретроспективне дослідження підсумково-звітної статистичної документації Національного канцер-реєстру (www.ncru.inf.ua) з використанням методу викопіювання даних.

Віковим контингентом для дослідження виокремлено доросле населення регіону та України.

Для оцінки організації онкологічної допомоги хворим на рак шлунка у Вінницькій області та Україні обрано такі тренди: захворюваність і смертність на 100 тис. населення, відсоток осіб, які не прожили одного року, з числа вперше захворілих, занедбаність (\%), морфологічна вери- 
фрікація (\%), охоплення спеціальним лікуванням первинних хворих (\%), загальна летальність (\%); середня частота госпіталізації хворого за рік, середній ліжко-день на одного хворого і однієї госпіталізації.

Отримані абсолютні й похідні величини, за досліджуваний 5-річний період, сфрормовано в динамічні ряди з 2-річним інтервалом й проведено їх обробку за показником наочності (ПН).

Методи дослідження: бібліосемантичний для вивчення вітчизняного та світового науково-інформаційного простору щодо досліджуваної проблеми, епідеміологічний - для вивчення основних трендів: поширеність і захворюваність, не прожили одного року з числа вперше захворілих, занедбаність, морфологічна верифікація, охоплення спеціальним лікуванням первинних хворих, середня частота госпіталізації хворого за рік, середній ліжко-день, загальна летальність від раку шлунка серед дорослого населення регіону та України, медико-статистичний - для збору, обробки та аналізу інфрормації, отриманої під час дослідження.

Результати дослідження та їх обговорення. Україна у повній відповідності до затверджених міжнародних стандартів та державного законодавства, у тому числі наказу МОЗ України від 17.09.2007 р. № 554 «Про затвердження протоколів надання медичної допомоги за спеціальністю «Онкологія». Рак шлунка» [2], проводить в онкогастроентерології клінічні дослідження для покращення виявлення, ранньої діагностики, лікування РШ.

Станом на 01.01.2020 р. кількість хворих на рак шлунка в Україні становила 27407 осіб (76,8 на 100 тис. населення). За статевим поділом чоловіки у 1,5 раза частіше хворіли на РШ, що склало 91,3 (15 146 осіб) до 64,2 (12 201 жінок) на 100 тис. населення. Таке ж співвідношення спостерігали щорічно протягом усього періоду дослідження. У структурі контингентів хворих за первинною локалізацією злоякісних новоутворень рак шлунка незмінно, з 2015 до 2019 р., займав у чоловічого населення восьме місце, у жіночого - одинадцяте.

Поглиблений аналіз показників структури захворюваності й смертності від ЗН у людини за статево-віковою характеристикою виявив такі особливості: питома вага раку шлунка у чоловіків відповідала четвертому (6,9 \%) й другому (9,5 \%), у жінок - восьмому (4,1 \%) й третьому (7,5 \%) місцям відповідно без їх змін протягом усього 5-річного періоду наукового пошуку.

Варто відзначити існування вікових коливань показника в динаміці у структурі захворюваності серед чоловічого контингенту, а в структурі смертності - серед жіночого. Так, у 2019 р. РШ у чоловіків розподілявся у вікових групах таким чином: 30-54 роки - 6,3 \% (четверте), 55-74 роки -
7,2 \% (четверте), 75+ років - 6,8 \% (п'яте) місця, тоді як у попередні роки посідав третє місце (7,17,3 \%) у віковій групі 30-54 роки. У жіночій віковій когорті 75+ років РШ займав незмінне четверте місце (6,6-5,9 \% (у 2019 р.)) щорічно за його відсутності у молодшому віці.

У віковій структурі смертності від ЗН рак шлунка посідав у чоловіків друге місце у вікових когортах 30-54 роки (9,3 \%) й 55-74 роки $(9,5 \%)$ i третє - у $75+$ років $(9,9 \%)$, серед жінок - четверте $(6,6 \%)$ у 30-54 роки й третє - у 55-74 роки (7,3\%) і $75+$ років (8,6 \%) без коливань у динаміці, а в 2016 р. ще й у групі 18-29 років померло 8,2 \% (четверте місце). Останнє вказує на недоліки роботи первинної ланки надання медичної допомоги населенню в напрямках ранньої діагностики РШ, виявлення передракових станів, скринінгу осіб із груп ризику, застосування профрілактичних технологій, особливо серед студентської молоді.

Посилює таке твердження і аналіз-зіставлення вікових індикаторних показників захворюваності до смертності від РШ. У структурі захворюваності населення України від 3Н рак шлунка у жінок спостерігали лише у віці 75+ років, тоді як смертність у них зайняла четверте місце уже у віці 30-54 роки, тобто помирає молоде економічно активне репродуктивне жіноче населення, що вкрай негативно характеризує діяльність системи охорони здоров'я загалом і онкологічної служби зокрема.

При порівнянні загальних показників захворюваності й смертності від злоякісних новоутворень шлунка зі світовими стандартами (табл. 1) відзначено їх перевищення у 1,8 раза (у 2019 р. на 100 тис. населення): захворюваність - 20,9 до 11,4, смертність - 15,3 до 8,2 відповідно.

За 2015, 2017, 2019 рр. відзначали постійне зниження загальних показників від раку шлунка як в Україні, так і у Вінницькій області, показник наочності яких становив: захворюваність - ПН (-) 5,9 \% і (-) 18,8 \%, смертність - (-) 7,8 \% і (-) 6,6 \% відповідно.

На наступному етапі наукового пошуку проведено оцінку стану організації онкологічної допомоги хворим на РШ із метою визначити її еорективність за такими основними трендами: не прожили одного року з числа вперше виявлених (дорічна летальність); занедбаність; морфологічна верифікація; охоплення спеціальним лікуванням первинних хворих (табл. 1).

3'ясовано, що вагомими недоліками в організації лікувально-діагностичного процесу цій категорії пацієнтів є результативні індикатори дорічної летальності та занедбаності хвороби, останній у 2019 р. склав 38,2 \% по Україні та 43,4 \% у Вінницькій області, тобто кожен третій випадок. Більшість (55,5 \%) з числа вперше виявлених не прожили одного року з моменту встановлення діагнозу, 
Таблиця 1. Показники захворюваності, смертності, організації онкологічної допомоги населенню за нозологічною формою «Рак шлунка», 2015, 2017, 2019 рр.

\begin{tabular}{|c|c|c|c|c|c|c|c|c|}
\hline \multirow{2}{*}{ Показник } & \multicolumn{2}{|c|}{2015} & \multicolumn{2}{|c|}{2017} & \multicolumn{2}{|c|}{2019} & \multicolumn{2}{|c|}{$\begin{array}{c}\Pi \mathrm{H}^{*}, \% \\
(+/-)\end{array}$} \\
\hline & Україна & perioн & Україна & регіон & Україна & регіон & Україна & perion \\
\hline $\begin{array}{l}\text { Захворюваність } \\
\text { (на } 100 \text { тис. населення)/ } \\
\text { світовий стандарт }\end{array}$ & $\begin{array}{c}22,2 / \\
12,3\end{array}$ & $\begin{array}{c}25,0 / \\
13,4\end{array}$ & $\begin{array}{c}21,3 / \\
11,6\end{array}$ & $\begin{array}{c}26,4 / \\
14,3\end{array}$ & $\begin{array}{c}20,9 / \\
11,4\end{array}$ & $\begin{array}{c}20,3 / \\
11,1\end{array}$ & $-5,9$ & $-18,8$ \\
\hline $\begin{array}{l}\text { Смертність } \\
\text { (на } 100 \text { тис. населення)/ } \\
\text { світовий стандарт }\end{array}$ & $\begin{array}{c}16,6 / \\
9,2\end{array}$ & $\begin{array}{l}21,3 / \\
11,1\end{array}$ & $\begin{array}{c}16,1 / \\
8,7\end{array}$ & $\begin{array}{l}20,4 / \\
10,9\end{array}$ & $\begin{array}{c}15,3 / \\
8,2\end{array}$ & $\begin{array}{l}19,9 / \\
10,5\end{array}$ & $-7,8$ & $-6,6$ \\
\hline Смертність/захворюваність & 74,8 & 85,2 & 75,6 & 77,3 & 73,2 & 98,0 & - & - \\
\hline $\begin{array}{l}\text { Не прожили одного року з } \\
\text { числа вперше виявлених у } \\
\text { попередньому році, \% }\end{array}$ & 59,4 & 62,0 & 58,1 & 62,6 & 55,5 & 61,1 & $-6,6$ & $-1,5$ \\
\hline Занедбаність, \% & 36,3 & 33,8 & 36,9 & 25,9 & 38,2 & 43,4 & $+5,2$ & $+28,4$ \\
\hline Морфологічна верифрікація, \% & 82,7 & 70,7 & 81,4 & 71,9 & 81,4 & 73,8 & $+0,6$ & $+4,4$ \\
\hline $\begin{array}{l}\text { Охоплення спеціальним } \\
\text { лікуванням первинних хворих, \% }\end{array}$ & 45,4 & 38,8 & 44,8 & 43,2 & 46,6 & 40,4 & $+2,0$ & $+4,1$ \\
\hline
\end{tabular}

Примітка. * - показник наочності (співвідношення даних 2019 р. до базового 2015 р., взятого за 100 \%).

при цьому регіональні показники вищі протягом усього періоду дослідження (61,1-62,6 \%).

Позитивним $\epsilon$ те, що дорічна летальність незначно зменшилась в динаміці, ПН якої становив (-) 6,6 \% й (-) 1,5 \% у Вінницькій області. Тоді як негативним доведеним фрактом $€$ показник дефектів - занедбаність - ПН (+) 5,2 \% і (+) 28,4 \% відповідно. Виявлено деяку невідповідність між цими показниками в 1,5 раза щорічно (у 2019 р. - 55,5 \% дорічна летальність до 38,2 \% занедбаність), що може бути причиною штучного заниження останнього як одного з рейтингових показників діяльності онкологічної служби.

Показано, що лише 45,0 \% первинних хворих у 2019 р. пройшли спеціальне лікування, в зв'язку 3 чим 55,0 \% прожило менше одного року з моменту встановлення діагнозу.

Для об'єктивізації оцінки стану організації онкологічної допомоги населенню рекомендують використовувати допоміжний критерій - співвідношення рівня смертність/захворюваність, що дозволяє виявити приховані системні недоліки. 3а 2015, 2017, 2019 рр. останній відповідав 73,275,6 \% по Україні та 77,3-98,0 \% - у Вінницькій області, тобто на кожних 100 зареєстрованих випадків захворювання припадало 73-98 смертей від раку шлунка.

Загальнодержавний і регіональний показники морфрологічної верифікації, за 5-річний період спостереження, зросли на (+) 0,6 \% й (+) 4,4 \% відповідно.

Підсумовуючи отримані дані, виявлено, що злоякісні новоутворення шлунка характеризувались високими показниками: занедбаності, дорічної летальності та смертності у співвідношенні до показника захворюваності.

Проведено аналіз регіональних показників діяльності стаціонарної ланки онкологічної служби за класифрікаційною групою «Злоякісні новоутворення шлунка» за 2015, 2017, 2019 рр. за такими критеріями: середня частота госпіталізації хворого за рік; середній ліжко-день на одного хворого і однієї госпіталізації; рівень загальної летальності (табл. 2).

Показано, що за досліджуваний період відбулося зростання двох показників - середньої частоти госпіталізації хворого за рік і середній ліжко-день на одного хворого, ПН яких склав (+)

Таблиця 2. Регіональні показники роботи стаціонару за класифікаційною групою «Злоякісні новоутворення шлунка» за 2015, 2017, 2019 рр.

\begin{tabular}{|l|c|c|c|c|}
\hline \multicolumn{1}{|c|}{ Показник } & 2015 & 2017 & 2019 & $\Pi^{*}, \%(+/-)$ \\
\hline Середня частота госпіталізації хворого за рік & 1,9 & 1,8 & 2,2 & $+15,8$ \\
\hline Середній ліжко-день на одного хворого & 20,0 & 17,9 & 20,3 & $+1,5$ \\
\hline Середній ліжко-день однієї госпіталізації & 10,4 & 9,8 & 9,4 & $-9,6$ \\
\hline Загальна летальність, \% & 1,0 & 0,9 & 1,0 & 0 \\
\hline
\end{tabular}

Примітка. * - показник наочності (співвідношення даних 2019 р. до базового 2015 р., взятого за 100 \%). 
$15,8 \%$ й (+) 1,5 \% і у 2019 р. становили 2,2 раза та 20,3 дня відповідно. При цьому показник середнього ліжко-дня однієї госпіталізації знизився на (-) 9,6 \% (9,4 дня у 2019 р.).

Рівень загальної летальності відповідав середнім загальнодержавним показникам якості надання медичної допомоги населенню хірургічного профрілю щорічно.

Отже, показники роботи стаціонару, особливо середня частота госпіталізації хворого за рік, доводять фракт занедбаності хвороби при первинному зверненні пацієнта та низької питомої ваги останніх, які були охоплені спеціальним лікуванням (лише кожен другий (46,6 \%)).

щоб нівелювати/знизити ризики виникнення вищевказаної ситуації в подальшому, виникає потреба в розробці алгоритму ранньої діагностики (РД) раку шлунка на первинній ланці, з урахуванням потенціалу системи охорони здоров'я країни, який ґрунтується на засадах «Руководства по ранней диагностике рака», розробленого ВОО3 [5]. Відповідно до нього, виділяють три етапи РД: перший - підвищення інфрормованості населення про симптоми раку шлунка та стимулювання звернень за медичною допомогою при їх виявленні (період самостійних дій пацієнта).

Другий етап - проведення клінічної оцінки, встановлення діагнозу і стадії процесу (період діагностики).

Лікар загальної практики/сімейний лікар повинен оцінити тривожні симптоми та обтяжливі фрактори (табл. 3).

Таблиця 3. Шкала обтяжливих фракторів

\begin{tabular}{|l|c|}
\hline \multicolumn{1}{|c|}{ Обтяжливий фрактор } & Кількість балів \\
\hline Вік: чоловіки >35 років, жінки >45 років & 2 \\
\hline Чоловіча стать & 2 \\
\hline Надлишкова маса тіла (індекс маси тіла >25) & 1 \\
\hline Вживання алкоголю >30 г/добу & 1 \\
\hline Тютюнокуріння >10 цигарок/день & 2 \\
\hline Застосування нестероїдних протизапальних препаратів та глюкокортикоїдів & 2 \\
\hline Виразка в анамнезі & 3 \\
\hline Рак шлунка/стравоходу в родичів пацієнта & \\
\hline
\end{tabular}

\section{Симптоми «червоних прапорців» («тривож- ні ознаки»)}

1. Ознаки шлунково-кишкової кровотечі (блювання з домішками крові, мелена).

2. Немотивована анемія.

3. Немотивована прогресуюча втрата маси тіла.

4. Прогресуюча дисорагія.

5. Персистуюче блювання.

6. Підвищення швидкості осідання еритроцитів, лейкоцитоз.

7. Надключична лімфраденопатія.

8. Симптоми диспепсії, які вперше виникли у віці старше 45 років.

Якщо сума балів, за шкалою обтяжливих факторів, перевищує 5, то пацієнту 3 диспепсією рекомендують проведення ендоскопічного обстеження 3 гастробіопсією та гістологічним дослідженням гастробіоптатів.

У разі потреби скерувати пацієнта на консультацію:

1. Хірурга (за наявності ознак ускладненого перебігу, внутрішньої кровотечі, стенозу воротаря, пенетрації, перфрорації).

2. Онколога (за наявності ознак неопластичного процесу в шлунку).

Лабораторні методи обстеження, на які скеровують пацієнтів сімейні лікарі, для визначення Нр-статусу:
1. Загальний аналіз крові.

2. Аналіз калу на приховану кров (при підозрі на шлунково-кишкову кровотечу).

3. Скринінговий метод діагностики інфекції Helicobacter pylori:

3.1. Каловий антигенний тест.

3.2. Серологічне дослідження.

3.3. С-сечовинний дихальний тест.

3.4. Дихальний Хелік-тест.

При Нр «+» статусі проводити ерадикацію відповідно до настанов Маастрихтського консенсусу V.

Третій етап - забезпечення належного лікування (період лікування).

Тривалість усіх трьох етапів, з моменту появи симптомів і до початку лікування, не повинна перевищувати 90 днів [5].

Для ранньої діагностики раку шлунка велике значення має диспансеризація осіб, які мають підвищений ризик розвитку цього захворювання пацієнти, старші 40 років з такою патологією, як: виразкова хвороба шлунка; поліпи шлунка; неепітеліальні пухлини шлунка; хронічний атрофрічний гастрит з кишковою метаплазією; хворі, які зазнали резекції шлунка; складчастий гіперпластичний гастрит (хвороба Менетрі); стравохід Барретта.

У групі ризику перебувають: чоловіки; пацієнти, які зловживають алкоголем та курять; наявність раку шлунка у кровних родичів; родинні ракові синдроми; пацієнти з А (II) групою крові. 
Особи з груп ризику повинні бути під динамічним спостереженням сімейного лікаря. Пацієнти з виразкою шлунка через 1 місяць після лікування повинні виконати контроль ФГДС з біопсією, в подальшому - через 6 місяців і перебувати під диспансерним спостереженням впродовж 5 років. У разі відсутності загострень і ознак «червоних прапорців» вони можуть бути зняті з диспансерного обліку.

Пацієнтам із поліпами шлунка, неепітеліальними пухлинами шлунка, хронічним атрофрічним гастритом, гіперпластичним гастритом, після резекції шлунка контроль ФГДС мають проводити один раз на рік. За ними необхідно вести активне спостереження зі щорічним ендоскопічним і рентгенологічним контролем, дослідженням калу на приховану кров кожних 6 місяців, тестуванням на Helicobacter pylori один раз на три роки та модифрікацією способу життя й режиму харчування.

щоб досягти максимальної ефективності ранньої діагностики РШ вирішальне значення має забезпечення достатнього потенціалу системи охорони здоров'я, який передбачає відповідне повноцінне матеріально-технічне оснащення і кваліфікований медичний персонал для своєчасного встановлення клінічного діагнозу, проведення патоморфологічного дослідження, променевої діагностики, встановлення стадії розвитку пухлинного процесу і своєчасного початку лікування.

\section{Висновки}

1. Станом на 01.01.2020 р. кількість хворих на рак шлунка в Україні становила 27407 осіб (76,8 на 100 тис. населення), серед них 15146 (91,3 на 100 тис. населення) чоловіків, які у 1,5 раза переважали кількість жінок - 12201 (64,2 на 100 тис. населення). У структурі захворюваності й смертності останній посідав у чоловіків четверте $(6,9 \%)$ й друге $(9,5 \%)$, у жінок - восьме $(4,1 \%)$ й третє (7,5 \%) місця відповідно протягом усього періоду спостереження.

2. З'ясовано, що вагомими недоліками в організації лікувально-діагностичного процесу цій категорії пацієнтів $€$ результативні індикатори дорічної летальності та занедбаності хвороби, останній у 2019 р. склав 38,2 \% по Україні та 43,4 \% у Вінницькій області, тобто кожен третій випадок. Більшість (55,5 \%) з числа вперше виявлених не прожили одного року з моменту встановлення діагнозу, при цьому регіональні показники вищі протягом усього періоду дослідження $(61,1-62,6 \%)$.

3. За 2015, 2017, 2019 рр. критерій співвідношення рівня смертність/захворюваність, що дозволяє виявити приховані системні недоліки, відповідав 73,2-75,6 \% по Україні та 77,3-98,0 \% - у Вінницькій області, тобто на кожних 100 зареєстрованих випадків захворювання припадало 7398 смертей від раку шлунка.

4. Доведено, що злоякісні новоутворення шлунка в Україні характеризувались високими показниками: занедбаності (38,2 \%), дорічної летальності (55,5 \%), смертності у співвідношенні до показника захворюваності (73,2 \%) та збільшенням середньої частоти госпіталізації хворого за рік (2,2 раза; ПН (+) 15,8 \%).

Перспективи подальших досліджень. Передбачено проведення ситуаційного аналізу потенціалу системи охорони здоров'я України, включаючи оцінку витрат на протиракову боротьбу, охоплення населення відповідними послугами, перешкоди при наданні медичної допомоги та її якості.

\section{Список літератури}

1. Аксель Е. М. Статистика злокачественных новообразований желудочно-кишечного тракта / Е. М. Аксель // Сибирский онкологический журнал. - 2017. - № 16 (3). - С. 5-11.

2. Про затвердження протоколів надання медичної допомоги за спеціальністю «Онкологія». Рак шлунка : наказ МОЗ України від 17.09.2007 р. № 554 [Електронний ресурс]. - Режим доступу : https://www.medstandart.net. - Haзва з екрана.

3. Рак желудка. Эпидемиологические особенности на современном этапе [Электронный ресурс] / Н. А. Шаназаров, А. М. Машкин, Ж. К. Сагандыков, А. А. Мидленко // Современные проблемы науки и образования. - 2014. - № 4. Режим доступа : https://www.science-education.ru/ru/article/view?id=13863. - Название с экрана.

4. Рак шлунку : методичні рекомендації / Є. С. Готько, С. В. Жеро, Т. В. Довганич та ін. [Електронний ресурс]. 2011. - 13 с. - Режим доступу : https://www.uzhnu.edu.ua/en/infocentre/get/2699. - Назва з екрана.

5. Руководство по ранней диагностике рака [Электронный ресурс] / ВО3. - 48 с. - Режим доступа : https://www.apps. who.int. - Название с экрана.

\section{References}

1. Aksel, E.M. (2017). Statystyka zlokachestvennykh novoobrazovaniy zheludochno-kyshechnogo trakta [Statistics of malignant neoplasms of the gastrointestinal tract]. Sibirskyy onkologicheskyy zhurnal - Siberian Oncology Journal, 16 (3), 5-11 [in Russian].

2. (2007). Nakaz MOZ Ukrainy № 554 vid 17.09.2007 r. «Pro zatverdzhennia protokoliv nadannia medychnoi dopomohy za spetsialnistiu «Onkolohiia». Rak shlunka» [Order of the Ministry of Health of Ukraine No. 554 of September 17, 2007 "On approval of protocols for medical care in the specialty "Oncology". Stomach cancer"]. Retrieved from: https://www. medstandart.net [in Ukrainian]. 
3. Shanazarov, N.A., Mashkin, A.M., Sagandykov, J.K. \& Midlenko, A.A. (2014). Rak zheludka. Epidemiologicheskiye osobennosti na sovremennom etape [Stomach cancer. Epidemiological features at the present stage]. Sovremennyye problemy nauki i obrazovaniya - Modern Problems of Science and Education, 4. Retrieved from: https://www.scienceeducation.ru/ru/article/view?id=13863 [in Russian].

4. Hotko, Ye.S., Zhero, S.V., Dovhanych, T.V., Hotko, N.Ye., Hotko, I.Yu., Mashura, H.Yu., Melnyk, M.I., Pryhara, D.V., \& Tsyhyka, D.Y. (2011). Rak shlunku [Gastric cancer]. Retrieved from: https://www.uzhnu.edu.ua/en/infocentre/get/2699 [in Ukrainian].

5. Rukovodstvo po ranney diagnostike raka [Guidelines for the early diagnosis of cancer]. WHO. Retrieved from: https:// www.apps.who.int [in Russian].

\section{ORGANIZATION OF EARLY DIAGNOSTICS OF GASTRIC CANCER IN VIEW OF CURRENT POTENTIALS OF THE PUBLIC HEALTH SYSTEM}

O. M. Komar, N. M. Kizlova

M. Pyrohov Vinnytsia National Medical University, Vinnytsia, Ukraine

Purpose: to analyze the gastric cancer incidence and mortality, and the effectiveness of cancer care for this category of patients in Vinnytsia region and Ukraine.

Materials and Methods. An epidemiological cross-sectional retrospective study of the final statistical documentation with the National Cancer Registry for 2015, 2017, 2019 (www.ncru.inf.ua) was conducted using the data copying-out method. The following trends were chosen to assess the organization of cancer care for patients with gastric cancer in Vinnytsia region and Ukraine: prevalence, disease incidence, patients not survived one year of being newly diagnosed, neglected disease, morphological verification, coverage of primary patients with special treatment, average annual hospitalization incidence; average beds per one patient and one hospital admission case, and total mortality. Study methods - semantic, epidemiological, medical and statistical.

Results. As of January 1, 2020, 27.407 individuals (76.8 per 100.000 population), including 15.146 (91.3 per 100.000 population) of males, which 1.5 times outstripped females - 12.201 (64.2 per 100.000 population), suffered from gastric cancer in Ukraine. Regarding morbidity and mortality considerations, the gastric cancer ranked fourth (6.9\%) and second (9.5\%) in males, and eighth (4.1\%) and third (7.5\%) in females, respectively, throughout the observation period. Effective indicators of less-one-year mortality and neglected disease were found significant shortcomings in the organization of treatment and diagnostics for this category of patients, with the latter amounted to $38.2 \%$ and $43.4 \%$ in 2019 in Ukraine and in Vinnytsia region, respectively, i.e. every third case. More than half (55.5\%) of newly diagnosed did not survive one year following the diagnosis, with the regional rates higher than the nationwide figures throughout the study period (61.1-62.6\%).

Conclusions. Malignant neoplasms of the stomach in Ukraine were proved to have a high rate of neglected cases (38.2 \%), less-one-year mortality (55.5\%), the mortality/incidence ratio (73.2 \%), and a growing statistics of the average annual hospital admission rate (2.2 times; emergency cases - (+) $15.8 \%)$ ).

KEY WORDS: gastric cancer; disease incidence; mortality; early diagnostics.

Рукопис надійшов до редакції 07.09.2020 p.

\footnotetext{
Відомості про авторів:

Комар Олена Миколаївна - доктор медичних наук, професор кафедри соціальної медицини та організації охорони здоров'я Вінницького національного медичного університету ім. М. І. Пирогова; тел.: +38(097) 482-48-25. Кізлова Наталія Миколаївна - кандидат медичних наук, доцент кафедри соціальної медицини та організації охорони здоров'я Вінницького національного медичного університету ім. М. І. Пирогова, завідувач відділення гастроентерології Вінницької обласної клінічної лікарні ім. М. І. Пирогова, головний експерт області за фрахом «Гастроентерологія»; тел.: +38(097) 297-32-21.
} 